\title{
The great 1815 eruption of Tambora and future risks from large-scale volcanism
}

\author{
R. Gertisser ${ }^{1}$ and S. Self ${ }^{2}$
}

${ }^{1}$ School of Physical and Geographical Sciences, Keele University, Keele, ST5 5BG, UK; r.gertisser@keele.ac.uk

${ }^{2}$ Department of Earth and Planetary Science, University of California, Berkeley, CA, USA

The year 2015 marks the bicentenary of the largest eruption in recent historic times: the 10-11 April 1815 eruption of Mount Tambora, Indonesia. Two hundred years after the eruption, an incomplete or inaccurate record of large eruptions over the past millennia, and uncertainties in determining the true sizes of eruptions, hamper our ability to predict when the next eruption of this scale may occur. Such events would have catastrophic effects locally and, possibly, world-wide. The problem is compounded by a lack of detailed knowledge of how and over what timescales large magma reservoirs that feed such eruptions grow and assemble, and of the surface manifestations of these processes recorded through geophysical or geochemical monitoring techniques.

Tambora is a massive, shield-like volcano that occupies much of the Sanggar Peninsula in northern Sumbawa, part of the Lesser Sunda Islands in Indonesia (Fig. 1). The volcano reaches a height of $2850 \mathrm{~m}$, but before 1815, it may have been one of Indonesia's highest mountains, more than 4000 $\mathrm{m}$ in elevation. The climactic phase of the eruption on 10-11 April 1815, which followed almost a week of minor and intermittent explosions, caused the summit to collapse, forming a caldera 6.5 $\mathrm{km}$ wide and more than $1 \mathrm{~km}$ deep (Fig. 2). The great eruption of Tambora, as it is often called, shook the world. More than 10,000 people vanished on Sumbawa alone, most likely killed by pyroclastic flows, and the famine and disease that followed caused at least another 50,000 deaths on Sumbawa and the neighbouring islands. These figures, when considered in terms of the global reach of the eruption, with world-wide suffering, a mean global temperature decrease of $\sim 1^{\circ} \mathrm{C}$, and exceptionally cold conditions in Europe and northeastern North America in 1816, must be an underestimate. This is the greatest death toll attributed to any eruption.

The 1815 Tambora eruption is probably the largest caldera-forming eruption of the last few centuries. Recent estimates suggest an erupted magma (dense rock equivalent; DRE) volume of $30-50 \mathrm{~km}^{3}$. It is thought that this magma was a homogeneous trachyandesite that was stored in a shallow crustal reservoir before eruption. During the eruption, pyroclastic flows swept down all flanks of the volcano and into the sea (Fig. 3), extending the coastline of the Sanggar Peninsula and causing a tsunami that reached the small island of Moyo (or Mojo), parts of Sumbawa, and, as contemporary reports suggest, as far as eastern Java. Pumice and coarse ash fell close to the volcano on the Sanggar Peninsula, but the finest volcanic ash fell as far as western Java, some $1300 \mathrm{~km}$ from the source, and much was deposited into the sea (Fig. 3). Remobilisation of the volcanic deposits on land, and the fact that a significant portion of the 1815 ejecta flowed or fell 
into the sea, make an accurate determination of the eruption volume difficult. For some, if not most of the older large Holocene eruptions, a few of which were likely to be significantly larger than Tambora, the erupted volumes reported may be even less accurate. Constraining the true size and recurrence times of these large eruptions is more than just scientific curiosity, as the answers affect our ability to forecast when the next one might happen.

\section{The present record of large past eruptions}

Volcanic eruption sizes are described using the Volcanic Explosivity Index (VEI), with values ranging from 0 (gentle) to 8 (colossal), or magnitude, a measure of the mass of magma erupted derived from deposit volumes. The largest known Holocene eruptions, characterised by either a VEI of 7 or

a magnitude $>6.8$, corresponding to $\sim 25 \mathrm{~km}^{3}$ or $\sim 6 \times 10^{13} \mathrm{~kg}$ of 'dacitic' magma, are listed in Table 1. Tambora 1815 is probably the largest eruption since 1257 when the Samalas eruption on the neighbouring island of Lombok occurred (Fig. 1). Between the two events, the eruption of Kuwae, a submarine caldera in Vanuatu, might have been of similar size, although little is known about the eruption itself. The AD $232 \pm 5$ Taupo eruption and the 'Millennium eruption' of Changbaishan or Baitoushan might have been slightly smaller than that of Tambora in 1815. In order to find an eruption that is assuredly bigger than Tambora's, we have to go back as long ago as 3600 years. Then, the Minoan eruption of Santorini seems to have formed a bigger caldera than Tambora's, and was probably larger in erupted magma volume. The eruption of Cerro Blanco, 4200 years ago, is regarded as the largest in the Central Volcanic Zone of the Andes in the last 5000 years, but the eruption volume is still poorly constrained. Going back to 5350 BC (7300 cal BP), the Kikai caldera eruption, Japan, was almost certainly larger than that of Tambora, as were the calderaforming eruptions of Mount Mazama (Crater Lake) 7700 years ago and the Kurile Lake eruption (Kamchatka) some 750 years earlier. These are just the eruptions for which a record exists.

\section{Eruption record, size and recurrence time of large eruptions}

Our record of past large eruptions, even when looking back only as far as the beginning of the Holocene (Table 1), is likely to be incomplete. Traces of these eruptions may be found in ice cores, but the volcanic source is not always clear. The Samalas eruption, part of the Rinjani volcanic complex on Lombok, is testimony to this point. Ice-core evidence from Greenland and Antarctica for a large, sulphur-producing eruption at this time, similar in size to Tambora in 1815 , has been available since the 1990s, yet the source volcano was only proposed in 2012. Similarly, the submarine Kuwae caldera in Vanuatu, which erupted in AD 1452, was only discovered in the mid1990 s because ice-cord records identified a spike in acidity indicative of volcanism at that time, prompting a search for the source.

For some prominent ice-core acidity spikes in the Holocene record that hint at a large tropical eruption in 1809, and for many of the smaller spikes, the volcanic source is yet to be identified. For others, the correlation with documented volcanic eruptions is still debated. An example of this is the pronounced $1642 \pm 5 \mathrm{BC}$ acidity signal in Greenland ice cores, which, aided by chemical analyses of minute tephra particles preserved in the ice, has been linked to Aniakchak volcano in 
Alaska, challenging the previous assignment of the Minoan eruption of Santorini as the source. A new precise radiocarbon date that places the Minoan eruption between 1627 and 1600 BC supports the proposed correlation with Aniakchak, but demonstrates that large magnitude eruptions do not always produce detectable acidity layers in ice cores. There is no other major acidity peak in Greenland ice cores at around that time. A good example that illustrates this point is the 'Millennium eruption' of Changbaishan, which suggests that either the eruption did not release large amounts of sulphur, or that the stratospheric sulphuric aerosols were not transported to arctic regions. Matters are complicated further by the fact that even smaller eruptions, like the 1982 eruption of El Chichón in Mexico, can deposit significant amounts of sulphuric aerosols on the polar ice sheets and glaciers. The conclusion has to be that many more large magnitude eruptions may not be recognised in existing records and, further, that estimates of the sizes (volumes) of eruptions inferred from acid concentrations in ice cores are prone to significant error.

Accurate volumes of past eruptions are notoriously difficult to obtain. The explosively distributed deposits are remarkably widespread, and tephra often falls or flows into the sea. The ash layers recovered in deep-sea cores may not reflect the primary thickness, and contributions from both Plinian and co-ignimbrite ash fall may complicate reconstructions of tephra dispersal patterns and, hence, calculations of tephra and erupted magma volumes. Another factor that may contribute to this problem is that the remaining deposits on land are rapidly eroded. For example, sixty percent of the 1991 Pinatubo (Philippines) pyroclastic flow deposits, an eruption significantly smaller than Tambora 1815, were remobilised in some areas within three to five years of the eruption. The most recent estimates of the erupted magma volume from Tambora during the April 1815 eruption range between 30 and $50 \mathrm{~km}^{3}$. However, the reported size range is, in particular when earlier estimates are also considered, extremely large. The eruption style included both an eruption column that injected material into the stratosphere and pyroclastic flows that shed material onto the volcano flanks (Fig. 3), often synchronously. Much of the ash fall occurred at sea, and an unknown amount of pyroclastic flows reached the coast and entered the sea (Fig. 3), so that we may never know the true erupted volume. Although the size of the caldera gives some indication of the amount of magma ejected, calderas are prone to rapid filling, wall collapse during the eruption, and other processes that quickly change the primary dimensions. Also, coalescence with previous calderas is common. The 1815 eruption was not the first explosive event at Tambora and two earlier eruptions may have contributed to a caldera that was enlarged in 1815 . For Samalas and Kuwae, the previous large magnitude eruptions, we are faced with some of the same issues, amplified, in the case of Kuwae, by its submarine setting. The volumes of both of these exceptional eruptions are still under scrutiny.

With an eruption record that is likely to be incomplete and a lack of accurate volume estimates for the largest, most catastrophic, but rare eruptions, determining their recurrence time is particularly difficult. The statistical models used to assess volcanic hazards rely on information about the timing and volumes of past events. If there are several eruptions missing from our records, the statistics for predicting the likelihood for future events of this size would change significantly. Making allowance for under-reporting of eruptions in the past record, one recent study suggests 
that the recurrence interval for the range of sizes reported for the Tambora 1815 eruption might vary from about 780 years for the low-end estimate (magnitude 6.9; $30 \mathrm{~km}^{3} \mathrm{DRE}$ ) to about 1500 years for the latest estimate (magnitude 7; $40 \mathrm{~km}^{3} \mathrm{DRE}$ ), and even 5,000 years for the largest estimates of erupted volume or mass (about magnitude $7.1 ; \sim 50 \mathrm{~km}^{3} \mathrm{DRE}$ ). Such a range in the perceived likelihood of a future eruption makes the urgency of realizing that an event of similar size might occur very different.

\section{Environmental effects from a future Tambora-size eruption}

The year 1816, the "Year Without a Summer" in Europe and northeastern North America, is the best-known case of a volcanically induced climate cooling event. The sulphur gases released by the highly explosive Tambora eruption resulted in an increase in stratospheric sulfate aerosols and a net cooling in 1815-1816. The cold climate was responsible for widespread crop failures, leading to serious famine and high food prices in Europe and North America, as well as agricultural stresses in Asia. Recent climate simulations performed with an atmospheric model show a global temperature decrease of $1.0 \pm 0.1^{\circ} \mathrm{C}$, agreeing with earlier estimates, and also a global precipitation decrease. Model results suggest there was a net primary productivity increase caused by strongly reduced plant respiration in 1816, and an overall increase in land carbon storage after the eruption. Such effects could accompany future Tambora-size eruptions, but may not be more severe, as recent atmospheric modelling has revived the idea of a 'ceiling' for the radiative effects of volcanic aerosols, which Tambora probably met.

\section{Anticipating a future Tambora-size eruption}

Large, caldera-forming eruptions with potentially global effects on the environment and climate are difficult to anticipate. Processes inside a volcano in the build-up of an eruption are typically accompanied by geophysical and/or geochemical signals that can be recorded the surface. However, to this day no eruption in the size range of the 1815 Tambora event has been monitored prior to the event. Moreover, the monitoring signals from recent episodes of unrest at resurgent calderas are now linked to complex magmatic or hydrothermal processes that have proved difficult to interpret. What, and how long, does it take for a volcano to evolve towards a largemagnitude eruption? A closer look at Santorini volcano (Fig. 4), site of the great Late Bronze Age or Minoan eruption (Table 1), may provide important clues to answer these questions. For the Minoan eruption, many of the crystals in the erupted products record replenishment of the Minoan magma reservoir by large batches of magma that occurred less than a century, and up to the final months, before the eruption. This work suggests that large bodies of eruptible magma may grow incrementally by influx of smaller volumes of magma into an existing reservoir, and that the final assembly of a large magma reservoir may occur on rapid timescales that can be much shorter than any preceding period of quiescence. In the light of these results, the inferred intrusion of magma into the shallow volcanic edifice during the 2011 unrest period may be regarded as a smaller magma batch that might contribute to incremental growth and assembly of a larger magma reservoir beneath Santorini with time. In such a scenario, smaller eruptions like 
the one in 1950, the latest in the history of Santorini volcano, may be merely no more than 'leaks' from a growing magma body.

Turning to Tambora, increased seismic activity and steam venting between April and September 2011 (and again in April 2013), and evidence for a few small post-1815, intra-caldera eruptions, indicate some parallels with Santorini, as does petrological work that suggests that the 1815 magma probably accumulated and differentiated in a shallow crustal reservoir over timescales of several thousand years. However, with a surprising paucity of studies on Tambora and its 1815 eruption, and no detailed field work being conducted there since the 1980s, many important questions regarding the geochronology of the volcano, why Tambora changed its eruptive style throughout its history, and details of the type and size of the 1815 eruption products, remain ripe for study. This knowledge is important for many reasons, if not only for the hazard predictions for Earth's next large (VEI or magnitude 7) eruption, and its effect on our modern society.

\section{Suggestions for further reading}

Crosweller, H.S., Arora, A., Brown, S.K., Cottrell, E., Deligne, N.I., Ortiz Guerrero, N., Hobbs, L., Kiyosugi, K., Loughlin, S.C., Lowndes, J., Nayembil, M., Siebert, L., Sparks, R.S.J., Takarada, T. \& Venzke, E., 2012. Global database on large magnitude explosive volcanic eruptions (LaMEVE). Journal of Applied Volcanology, v.1, doi:10.1186/2191-5040-1-4.

Deligne, N.I., Coles, S.G. \& Sparks, R.S.J., 2010. Recurrence rates of large explosive volcanic eruptions. Journal of Geophysical Research, v.115, B06203, doi:10.1029/2009JB006554.

Druitt, T.H., Costa, F., Deloule, E., Dungan, M. \& Scaillet, B., 2012. Decadal to monthly timescales of magma transfer and reservoir growth at a caldera volcano. Nature, v.482, pp.77-80.

Friedrich, W.L., Kromer, B., Friedrich, M., Heinemeier, J., Pfeiffer, T., Talamo, S., 2006. Santorini eruption radiocarbon dated to 1627-1600 B.C. Science, v.312, pp.548.

Gertisser, R., Self, S., Thomas, L.E., Handley, H.K., van Calsteren, P. \& Wolff, J.A., 2012. Processes and timescales of magma genesis and differentiation leading to the great Tambora eruption in 1815. Journal of Petrology, v.53, pp.271-297.

Hogg, A., Lowe, D.J., Palmer, J., Gretel, B. \& Bronk Ramsey, C., 2011. Revised calendar date for the Taupo eruption derived by ${ }^{14} \mathrm{C}$ wiggle-matching using a New Zealand kauri ${ }^{14} \mathrm{C}$ calibration data set. The Holocene, v.22, pp.439-449.

Kandlbauer, J. \& Sparks, R.S.J., 2014. New estimates of the 1815 Tambora eruption volume. Journal of Volcanology and Geothermal Research, v.286, pp.93-100.

Kandlbauer, J., Hopcroft, P.O., Valdes, P.J. \& Sparks R.S.J., 2013. Climate and carbon cycle response to the 1815 Tambora volcanic eruption. Journal of Geophysical Research: Atmospheres, v.118, pp.12497-12507.

Lavigne, F., Degeai, J.-P., Komorowski, J.-C., Guillet, S., Robert, V., Lahitte, P., Oppenheimer, C., Stoffel, M., Vidal, C.M., Surono, Pratomo, I., Wassmer, P., Hajdas, I., Hadmoko, D.S. \& de Belizal, E., 2013. Source of the great A.D. 1257 mystery eruption unveiled, Samalas volcano, Rinjani Volcanic Complex, Indonesia. Proceedings of the National Academy of Sciences, v.110, pp.16742-16747. 
Oppenheimer, C., 2003. Climatic, environmental and human consequences of the largest known historic eruption: Tambora volcano (Indonesia) 1815. Progress in Physical Geography, v.27, pp.230-259.

Parks, M.M., Biggs, J., England, P., Mather, T.A., Nomikou, P., Palamartchouk, K., Papanikolaou, X., Paradissis, D., Parsons, B., Pyle, D.M., Raptakis, C. \& Zacharis, V., 2012. Evolution of Santorini volcano dominated by episodic and rapid fluxes of melt from depth. Nature Geoscience, v.5, pp.749-754.

Pearce, N.J.G., Westgate, J.A., Preece, S.J., Eastwood, W.J. \& Perkins, W.T., 2004. Identification of Aniakchak (Alaska) tephra in Greenland ice core challenges the 1645 BC date for Minoan eruption of Santorini. Geochemistry, Geophysics and Geosystems v.5, doi:10.1029/2003GC000672.

Self, S., Gertisser, R., Thordarson, T., Rampino, M.R. \& Wolff, J.A., 2004. Magma volume, volatile emissions, and stratospheric aerosols from the 1815 eruption of Tambora. Geophysical Research Letters, v.31, doi:10.1029/2004GL020925.

Self, S., Rampino, M.R., Newton, M.S. \& Wolff, J.A., 1984. Volcanological study of the great Tambora eruption of 1815. Geology, v.12, pp.659-663.

Siebert, L., Simkin, T. \& Kimberly, P., 2011. Volcanoes of the World (3 $3^{\text {rd }}$ edition). Berkeley and Los Angeles: University of California Press.

Sigurdsson, H. \& Carey, S., 1989. Plinian and co-ignimbrite tephra fall from the 1815 eruption of Tambora volcano. Bulletin of Volcanology, v.51, pp.243-270.

Stothers, R.B., 1984. The great Tambora eruption in 1815 and its aftermath. Science, v.224, pp.1191-1198.

Timmreck, C., Lorenz, S.J., Crowley, T.J., Kinne, S., Raddatz, T.J., Thomas, M.A. \& Jungclaus, J.H., 2009. Limited temperature response to the very large AD 1258 volcanic eruption. Geophysical Research Letters, v.36, doi:10.1029/2009GL040083.

Xu, J., Pan, B., Liu, T., Hajdas, I., Zhao, B., Yu, H., Liu, R. \& Zhao, P., 2013. Climatic impact of the Millennium eruption of Changbaishan volcano in China: new insights from high-precision radiocarbon wiggle-match dating. Geophysical Research Letters, v.40, doi:10.1029/2012GL054246.

Zielinski, G.A., Mayewski, P.A., Meeker, L.D., Whitlow, S., Twickler, M.S., Morrison, M., Meese, D.A., Gow, A.J \& Alley, R.B.,1994. Record of volcanism since 7000 B.C. from the GISP2 Greenland ice core and implications for the volcano-climate system. Science, v.264, pp.948952. 


\section{Tables}

Table 1. Large Holocene eruptions with a VEI of 7 or a magnitude $>6.8$ (data sources: Global Volcanism Program - Volcanoes of the World; Global database on large magnitude explosive volcanic eruptions - LaMEVE). The dates in brackets for the Changbaishan and Taupo eruptions are from newer studies.

\begin{tabular}{lll}
\hline Volcano & Country & Date \\
\hline Tambora & Indonesia & AD 1815 \\
Kuwae & Vanuatu & AD 1452 \\
Samalas (Rinjani) & Indonesia & AD 1257 \\
Changbaishan & China & AD $1000 \pm 40(946 \pm 3)$ \\
Taupo Ignimbrite & New Zealand & AD $233 \pm 13(232 \pm 5)$ \\
Santorini (Minoan) & Greece & $1610 \pm 14$ BC \\
Aniakchak & USA & $1645 \pm 10$ BC \\
Cerro Blanco & Argentina & $2300 \pm 160$ BC \\
Kikai & Japan & $\sim 5350$ BC \\
Mt. Mazama (Crater Lake) & USA & $5677 \pm 150$ BC \\
Kurile Lake & Russia & $6437 \pm 23$ BC \\
\hline
\end{tabular}




\section{Figures}

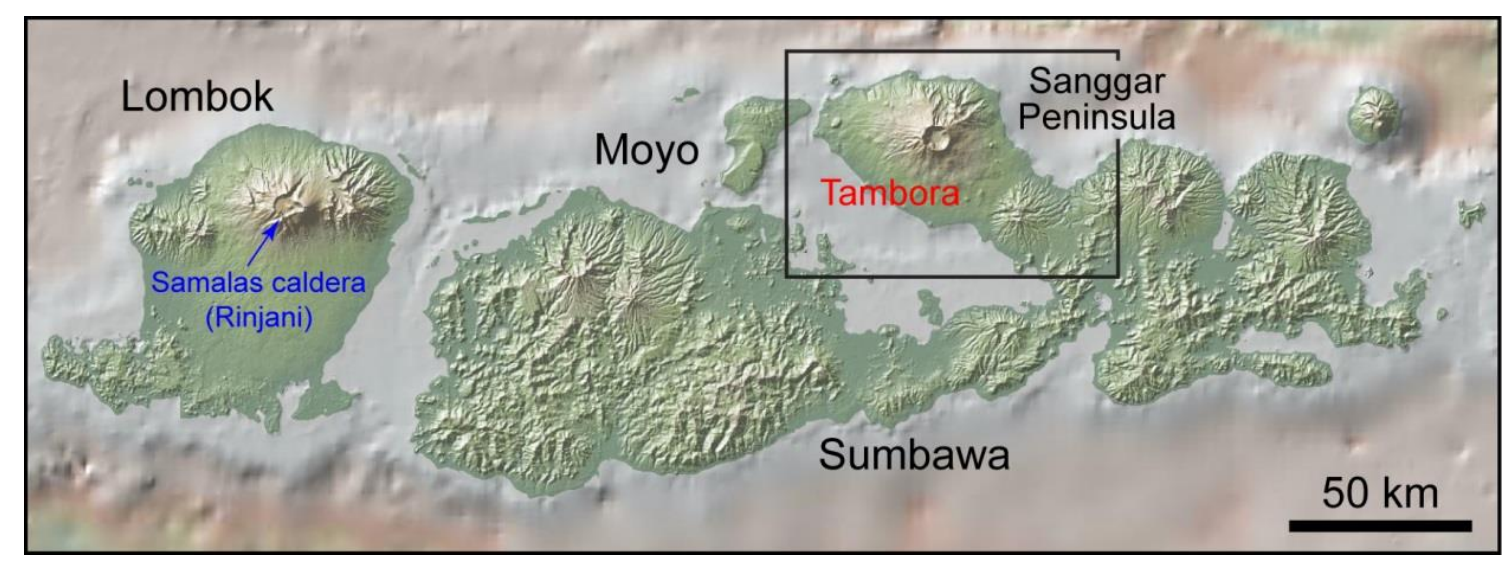

Fig. 1. Map of the Lombok-Sumbawa sector of the Sunda arc, Indonesia, showing the location of Tambora and Rinjani, the sites of what were probably the two largest eruptions of the last millennium. The box outlines the area displayed in Fig. 3a. The map was generated using GeoMapApp ${ }^{\circledR}$. 


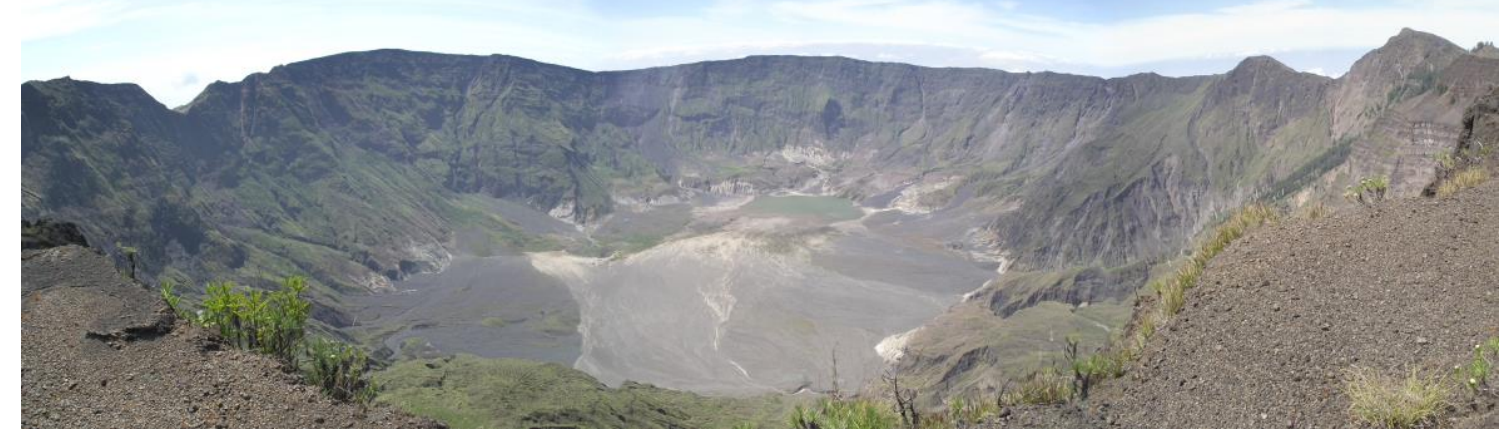

Fig. 2. The $7 \times 6 \mathrm{~km}$ wide and more than $1 \mathrm{~km}$ deep summit caldera of Tambora created by the 1815 eruption. The 1815 eruptive products form the top of the caldera wall, as seen in the foreground. On the floor of the caldera lie an ephemeral lake and a small cone from a post-1815 eruption. Photo by Katie Preece. 

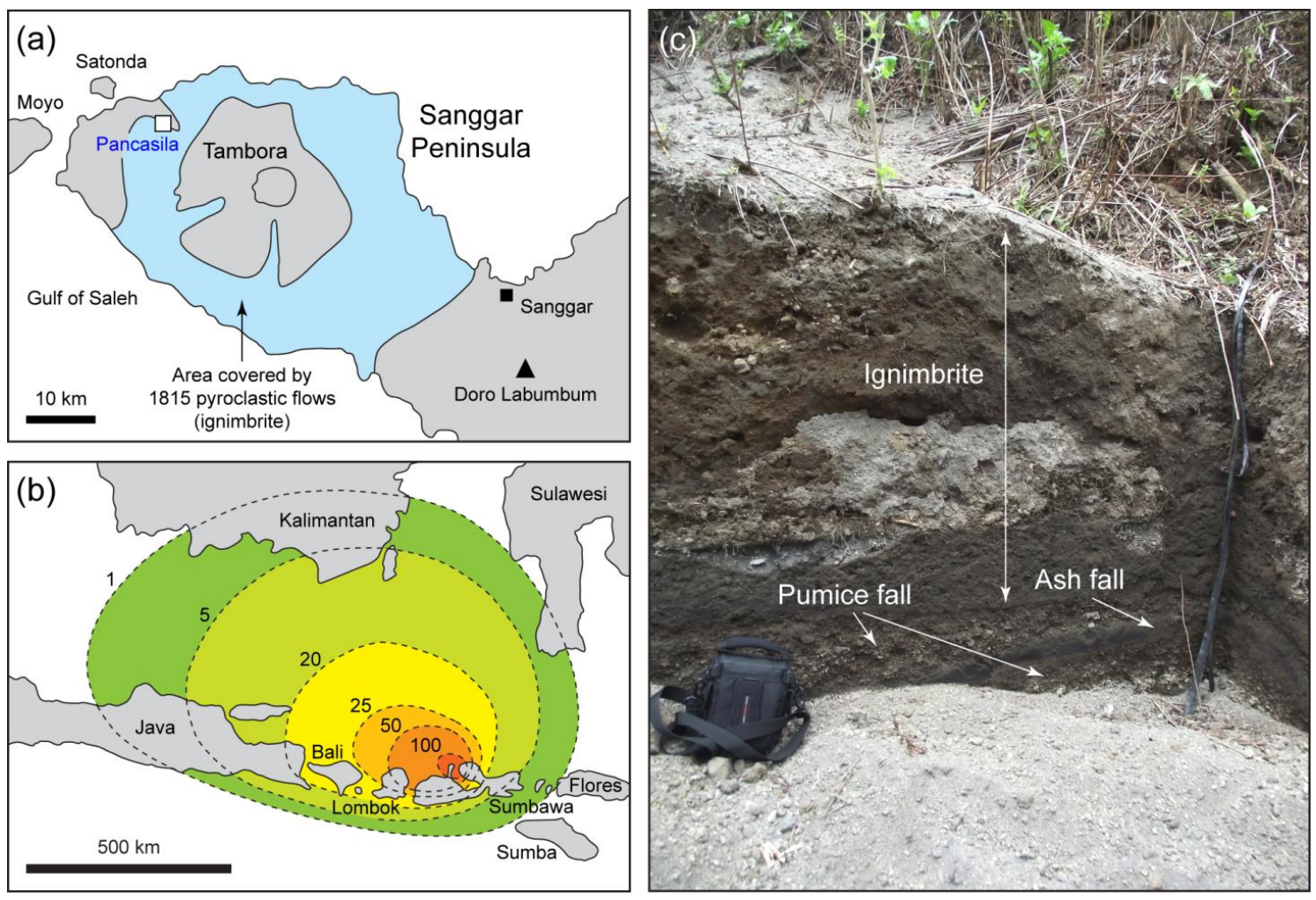

Fig. 3. (a) Sketch map of Tambora illustrating the distribution of ignimbrite from the 1815 eruption on the Sanggar Peninsula. (b) Distribution of the distal ash fall from the eruption. Isopach thicknesses are given in $\mathrm{cm}$. (c) Near-source deposits of the 1815 eruption near Pancasila (cf. Fig. 3a) on the northwestern flank of Tambora: alternating layers of pumice and ash fall deposits are overlain by pyroclastic flow deposits (ignimbrite). Photo by Katie Preece. 


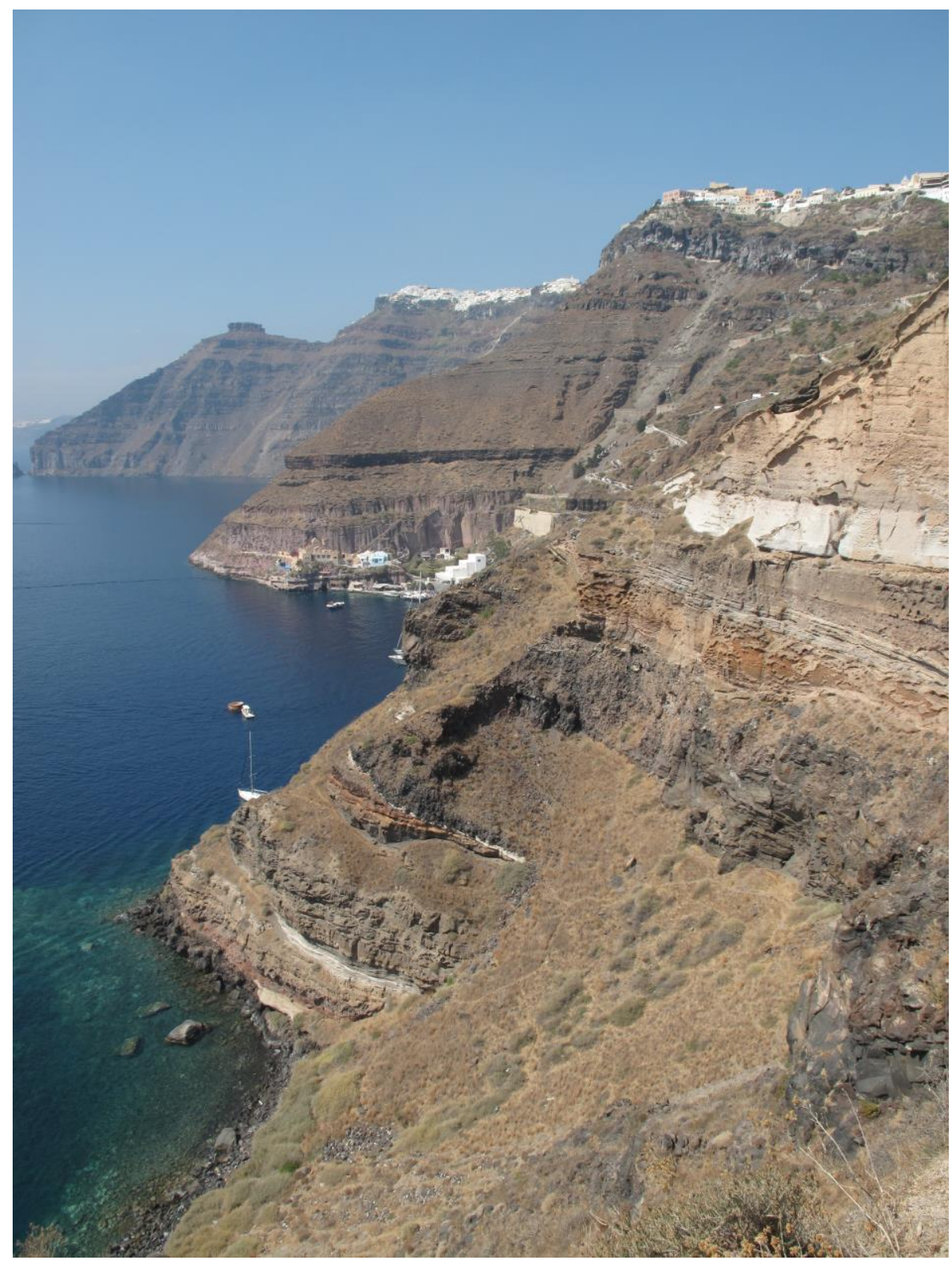

Fig. 4. The caldera wall of Santorini volcano, Greece. The present-day caldera is $10 \times 6 \mathrm{~km}$ wide, and formed by multiple collapses over the past $\sim 180,000$ years, the last of which occurred during the Minoan eruption. 